\title{
The Fate of the Remains and Funerary Equipment of Czech Rulers and Their Family Members
}

Introduction

Prague Castle was the most important burial site of the Czech rulers and their relatives. The graves are located in the Church of the Virgin Mary (Spytihněv I †9I5 and his wife), in St. George Church and Convent (St. Ludmila †92r; Boleslaus II †999; Vratislaus I †92 I; Oldřich? †934), and, in the greatest numbers, in St. Vitus Rotunda, which later became St. Vitus Basilica (St. Wenceslaus †935; Boleslaus I? †97ı; Bretislaus I †ı055; Spytihněv II †ı06I; Bretislaus II †ıIoo; Bořivoj II †II24; Ottokar I †I230; Rudolph I Habsburg †1307; Ottokar II †I278). In 1373 , these remains were transferred to the chancel chapel of the newly constructed Gothic cathedral.

As Emperor Charles IV intended to make St. Vitus Cathedral the final resting place for himself and his family, he had a masonry crypt built in the chancel, where his family members, the emperor himself and finally the kings of Bohemia from the $15^{\text {th }}$ and $16^{\text {th }}$ centuries were buried. Construction was launched in 1566 on a new royal crypt, the subterranean part of which was expanded to include a mausoleum on the ground level. The remains of the kings and their family members were moved here in 1580 (Blanche of Valois $\uparrow_{1348}$; Anne of Bavaria $\dagger_{1353}$; Anna von Schweidnitz †1362; Charles IV †1378; Joanna of Bavaria †1386; Elizabeth of Pomerania † 1393; John of Görlitz †1396; Wenceslaus IV † 4419; Ladislaus the Posthumous †i457; George of Podebrady †i47I; Eleonora †I580; Rudolph II †I6I2); 


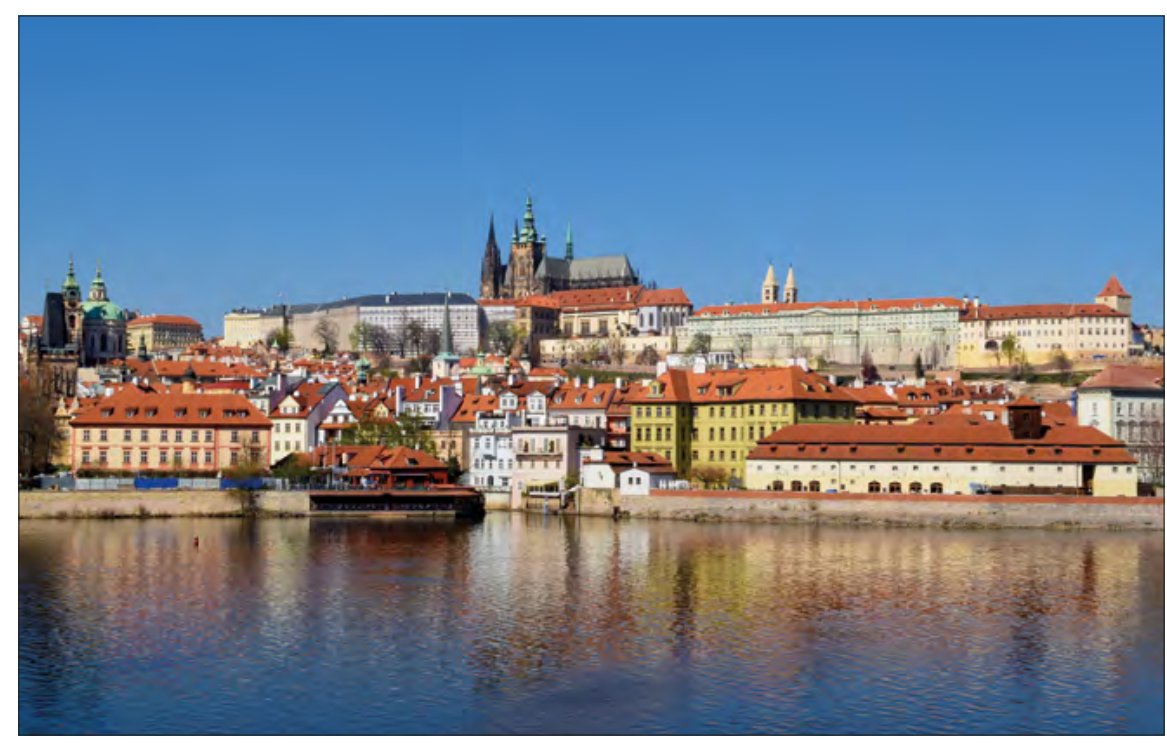

Fig. 1. Prague Castle. (C) Markéta Březinová.

Renaissance rulers were buried in the mausoleum (Ferdinand I 15564 ; Anne of Bohemia and Hungary I5 47 ; Maximilian II $\dagger_{1576}$ ).

Reliquary tombs of the most important Czech patron saints are also located at Prague Castle: St. Ludmila in St. George Basilica, St. Wenceslaus, St. Adalbert and St. John of Nepomuk in St. Vitus Cathedral and St. Procopius in All Saints Church.

We also know the graves of I2 Prague bishops (Šebír †1067; Gebhart †ıo9o; Kosmas †ı098; Menhart †ı134; Jan I †ı139; Daniel I †ı167; Friedrich von Putelendorf †ı179; Valentin †ı182; Ondřej †ı223; Jan II †ı236; Bernard †ı240; Mikuláš von Riesenburg †ı258; Jan III from Dražice †ı278; Tobiáš from Bechyně †ı296; Řehoř Zajíc from Valdek †ıวOI; Jan IV from Dražice †1343) that were originally located in the St. Vitus Rotunda and Basilica. Their remains were brought to the chancel of St. Vitus Cathedral in 1374 (for instance Bravermanová 2005; Lutovský, Bravermanová 2007; Bravermanová 2016).

\section{Opening the graves and handling the remains}

The majority of the aforementioned graves have been opened several times in the past for a variety of reasons, mainly because a better and more dignified location was sought and the disintegrating coffins were replaced by more lavish and durable sarcophagi. Graves were also opened in many cases due to reconstruction on the actively used grounds of Prague Castle. A turning point in this respect did not come 


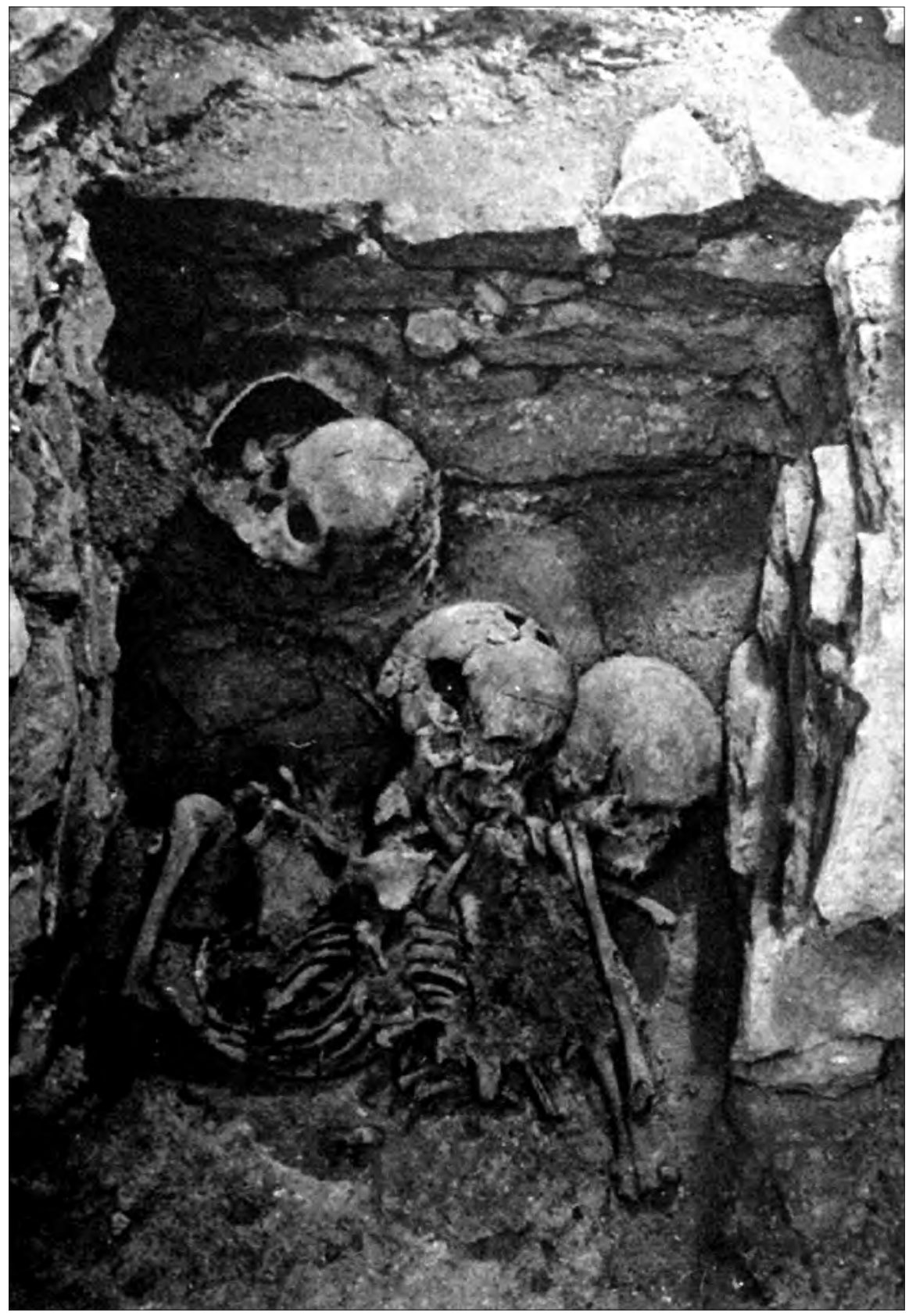

Fig. 2. Remains of Spytihněv I and his wife in the Church of the Virgin Mary (according to Vlček 1997: 87). 
until the $20^{\text {th }}$ century (Lutovský, Bravermanová 2007: 7-8). When the royal tomb in St. Vitus Cathedral was opened and remains were removed in 1928 , the aim was still to build a more dignified space for their deposition (Hilbert et al. 1928-1930). However, subsequent activity was guided more by the pursuit of archaeological and anthropological knowledge (Borkovský 1975; Bravermanová, Otavská 2013; Frolík et al. 1988; Matiegka 1932; Smetánka et al. 1986; Vlček 1997; 1999; 2000).

The reliquaries of the saints met a slightly different fate: their opening in the past was connected with the canonisation process and with interest in the relics. The St. Wenceslaus reliquary and its surroundings were investigated in the early $20^{\text {th }}$ century, at which time the first anthropological study was also conducted (Podlaha 19II). This then became the impulse for the later opening of the St. Adalbert, St. Ludmila and St. Procopius reliquaries (Bravermanová 2006; Vlček 1995).

The repeated opening of graves, the handling of remains and their transfer caused various problems, the most serious of which involved the confusion of relics. One of the first such cases was recorded as far back as the $14^{\text {th }}$ century by chronicler Beneš Krabice of Weitmil, who described the situation in the context of the construction of the Gothic cathedral (Beneš Krabice z Weitmile I884:

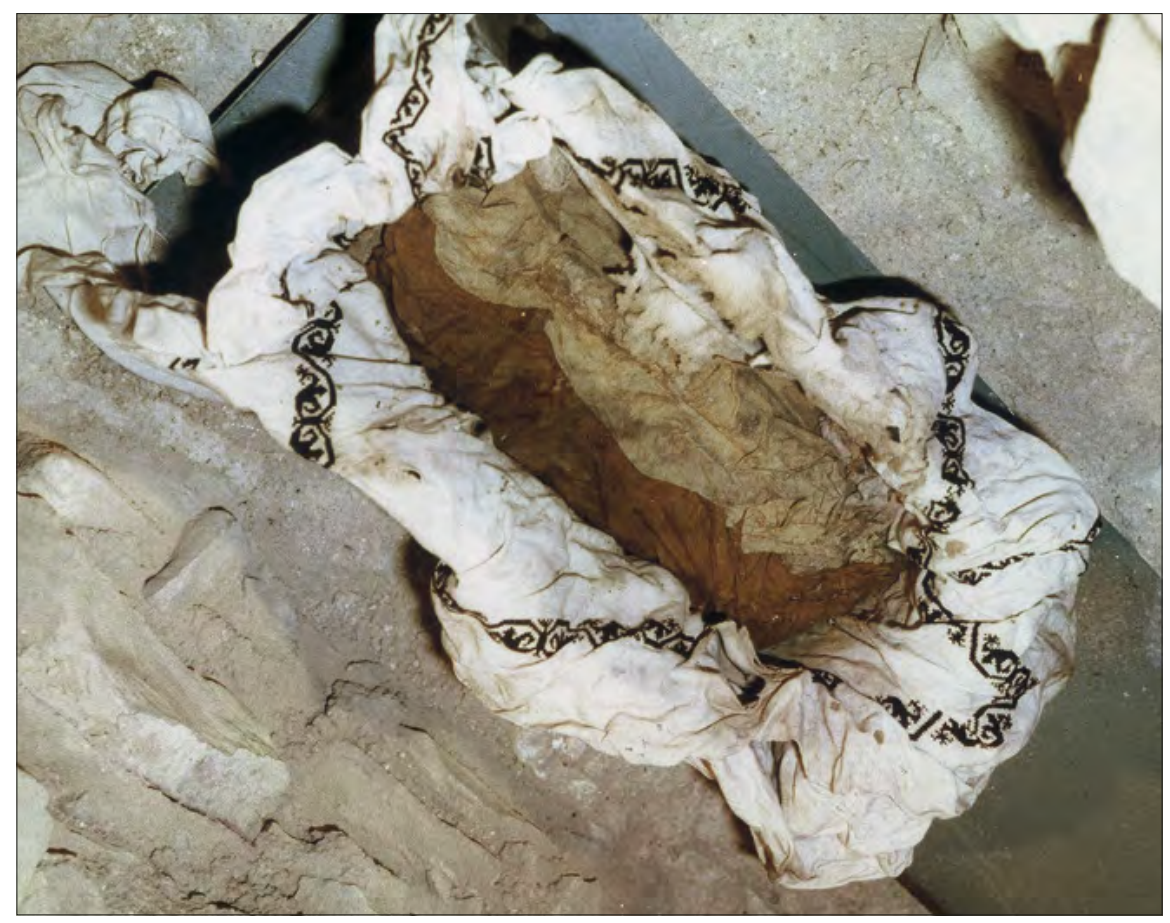

Fig. 3. Remains of St. Ludmila in the St. George Church (according to Vlček 1997: 69). 
547-548). Relics were also mixed during the modern investigation of the tomb of Bretislaus I, his wife Jitka and son Spytihněv II in 1978 and I983 (Frolík et al. 1988). In 2002, only children's and female skeletal remains were removed from the tomb of Bretislaus II instead of the anticipated male remains (Bravermanová, Otavská 2013). Also mixed at some point were the remains of the four wives of Charles IV, which were apparently placed in a single coffin in 1612 during the deposition of the large sarcophagus of Rudolph II in the royal crypt (Matiegka 1932). The final case that can be mentioned is the opening of the reliquary of St. Procopius in 1987, at which time it was discovered that none of the preserved relics could have belonged to him. It is therefore evident that during the transfer from the Sázava monastery to Prague Castle in 1588, the authentic relics of St. Procopius perhaps no longer existed (Bravermanová 2005: 104-107).

The manner in which the graves were opened in the $20^{\text {th }}$ century can already be regarded as building-historical and archaeological investigations. However, they were not always conducted in a proper manner, despite the fact that archive sources related to these activities mention the names of professionals. The tombstone of St. Wenceslaus was studied with relative care in I9II (Podlaha 1911) and

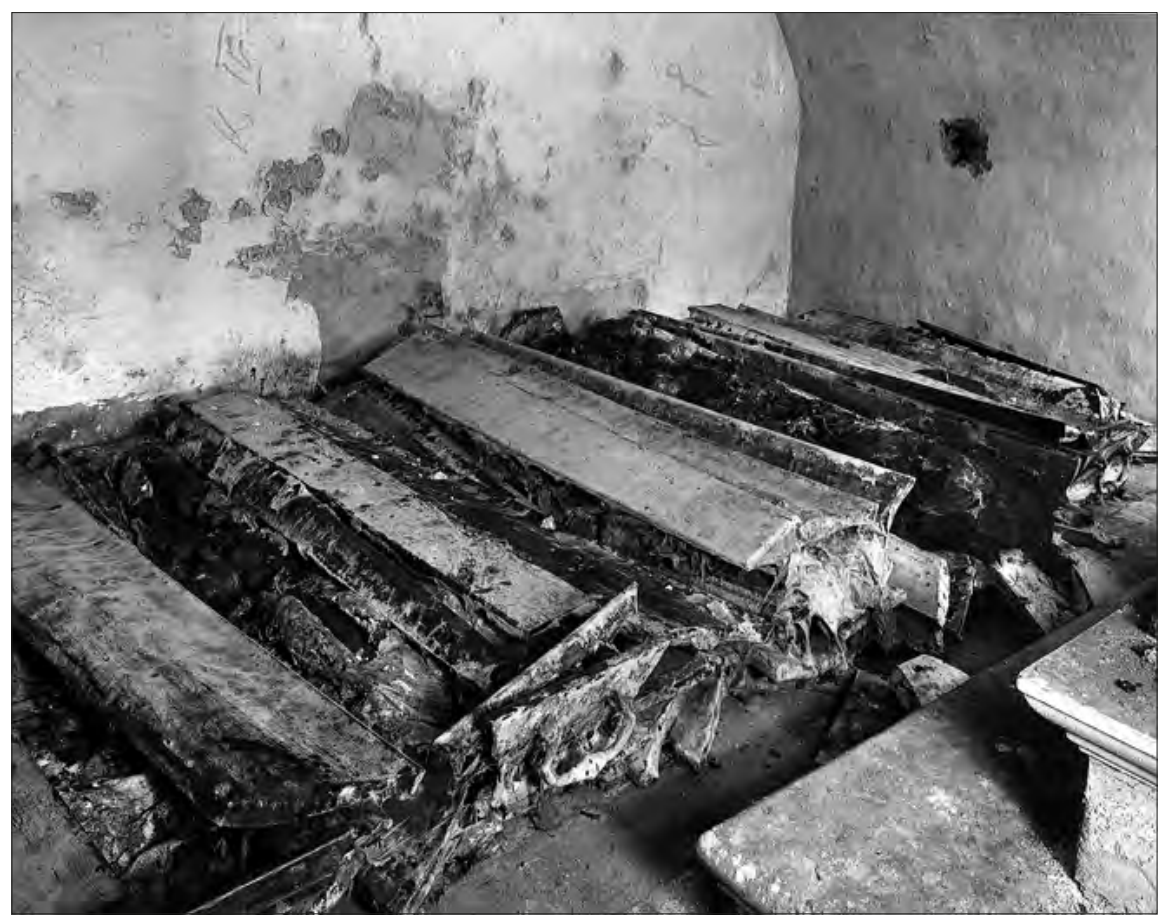

Fig. 4. The Royal Tomb in 1928 (according to Hilbert et al. 1928-I930: 245). 
the opening of the bishops' graves in 1928 was conducted with similar attention (Bravermanová 2004). However, the opening of old coffins and the removal of remains and grave furnishings from the royal crypt in the same year was far more problematic, with those performing this work failing to compile documentation in greater detail or to describe the content of individual coffins (Lutovský, Bravermanová 2007: 154-158).

The archaeological excavation of the Church of the Virgin Mary in 1950 (Borkovský 1953) and the St. George Basilica and Convent in 1959-1962 (Borkovský 1975) was conducted on the highest professional level for the period, including work in the field, the removal of remains and grave goods, as well as the documentation of all methods and discovered artefacts.

\section{Anthropological study}

The first systematic anthropological investigations were conducted at the beginning of the $20^{\text {th }}$ century. The foundation of the research was morphology, i.e. a description of the individual parts of bones, the identification of possible anomalies and

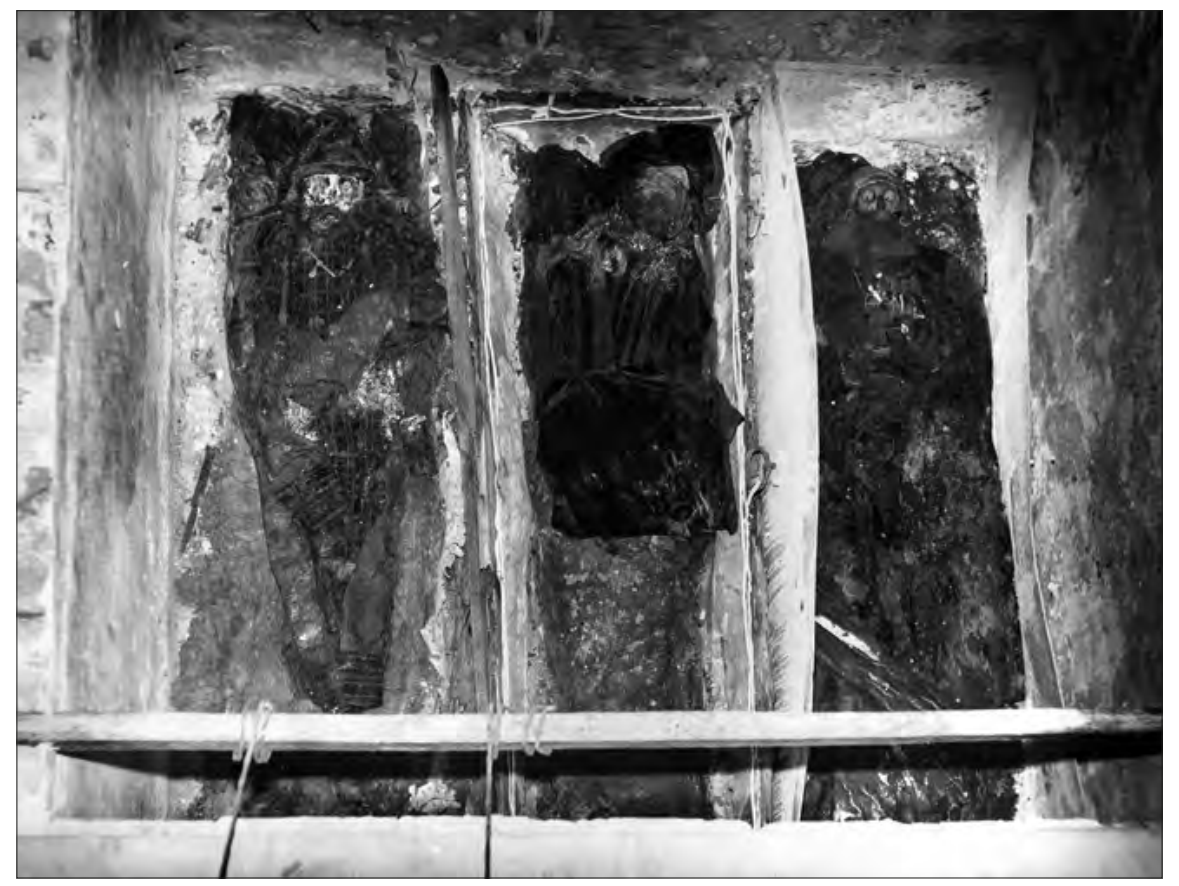

Fig. 5. Remains of Ferdinand I, Maximilian II and Anne of Bohemia and Hungary in the Renaissance mausoleum (according to Vlček 1997: 82). 


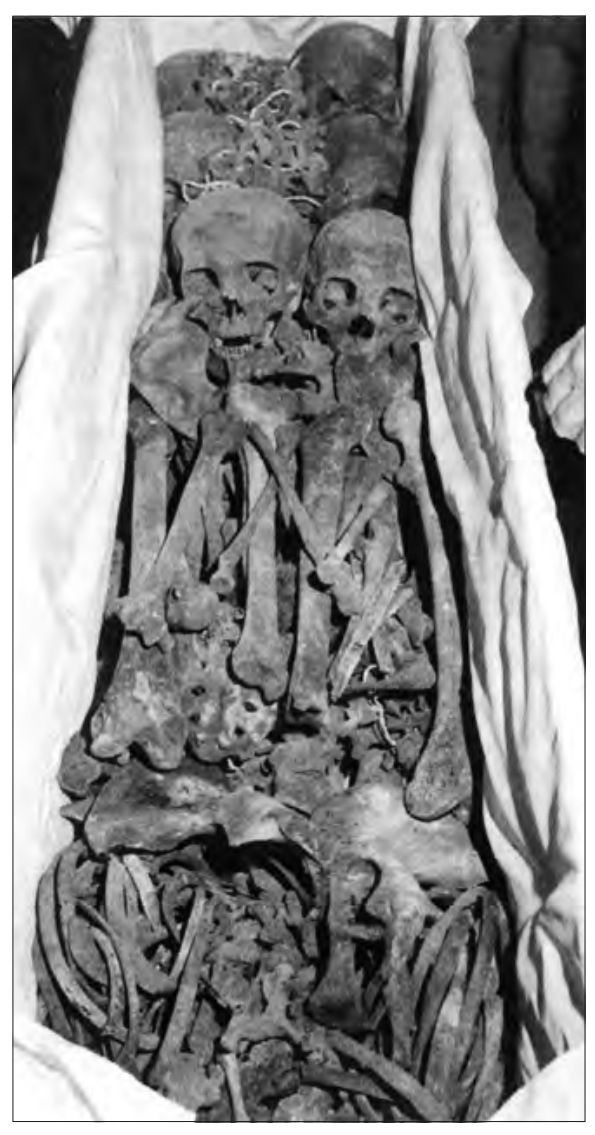

Fig. 6. Mixed up remains from the coffin of Czech queens (according to Vlček 1999: 210). an evaluation. One interesting method was an attempt to determine which skull and skeleton in the common coffin in the royal tomb belonged to which queen (Matiegka 1932). In addition to comparing the age of skulls and skeletons with their age at death, the method of superimposing the skulls on the busts on the triforium in St. Vitus Cathedral, of which it is said that they have very realistic traits, was also employed at the time (Matiegka 1932: 5, I3; Vlček 1999: 213). The remains of nearly all historical personalities buried at Prague Castle were available for another anthropological study conducted in the 1960s. Although more modern methods were utilised, the basis of the work was again morphology. Gustafson's method for determining age based on the condition of teeth was used for the first time (Vlček 1997). And yet, the interpretations often did not agree with historical information and triggered considerable debate. This method is now rejected by even anthropologists themselves (Sláma 1983; Brůžek, Novotný 1999).

Topics currently being addressed include a reconstruction of diet using analyses of stable nitrogen and carbon isotopes, the verification of residential mobility by means of analyses of strontium isotopes and the radiocarbon dating of selected samples. If possible, historical DNA is also analysed using methods of identification genetics enabling the classification of skeletal remains into family lines and the determination of family relationships between studied individuals (for instance, Bravermanová et al. 20I8). The results of these new investigations are in process and continuously published (Frolík, Kaupová 20ı6; Votrubova et al. 20I7; Kaupová et al. 2018; Saunders et al. 2019).

However, proving to be highly debatable are investigations in which archaeologists did not assist anthropologists in the opening of graves and tombs, as was the case in the 1970 s with the Renaissance mausoleum (Documentation on inv. 
no. PHA 24-26) and the tomb of Bretislaus I and Ottokar I in St. Vitus Cathedral and in 1974 with the important princely grave known as $\mathrm{K}_{\mathrm{I}}$ in the former St. Vitus Rotunda (Frolík 2005: 32). In contrast, the investigations of the tomb of Spytihněv II in 1983 (Frolík et al. 1988) and Bretislaus II in 2002 (Bravermanová, Otavská 2013) can be described as work conducted in a modern manner.

\section{Care of grave goods}

In the past, removed grave goods did not receive proper care for the most part, mainly due to a lack of understanding as to what constituted correct procedures for handling artefacts deposited for years in the unsuitable conditions of graves and tombs (Bravermanová et al. 20II). For example, many grave goods were not adequately labelled following their removal, e.g. the furnishings of the graves of the Prague bishops. In 1928, the objects were placed in glass frames, often with several units grouped together, but the frames were not adequately labelled. When the textiles and leather artefacts were handed over for restoration in 1985 , documentation of their initial condition was not compiled; moreover, the contents of the frames and their inventory numbers were again mixed, resulting in a situation in which the "artefacts were missing their bishop and the bishops were missing their grave goods". It was not until 2005 that all the preceding work was revised and a new interpretation was attempted (Bravermanová 2004).

The handling of the inventory of the royal tomb was similarly problematic. For example, soon after the opening of the crypt in 1928 , a ring with amethyst retrieved from the common grave of Charles Iv's wives was lost (Lutovský, Bravermanová 2007: 158). The situation surrounding textile finds is very complicated: the coffin from which these remnants of funeral robes and clothing accessories came from was not recorded. Although the concise publication released in 1937 provides a description and art history interpretation of twenty patterns, no effort was made to identify the discovered fabrics with the clothing of specific individuals (Gollerová-Plachá 1937).

Further confusion and especially losses occurred in the period in which copies of several textiles were acquired, as fragments of the original fabrics were handed over at the time to selected textile schools without proper records. According to a preserved report, a small number of the original textiles were returned in 1937 wrapped in a "single package", which was subsequently forgotten about over time before being discovered again by chance in 1979 (Documentation on the royal tomb; Bravermanová et al. 2005: 476).

The grave goods themselves were often restored in an inappropriate manner. The textiles from the royal tomb and from the graves of the Prague bishops were handed over for restoration in 1985 , but the resulting work was highly problematic. 


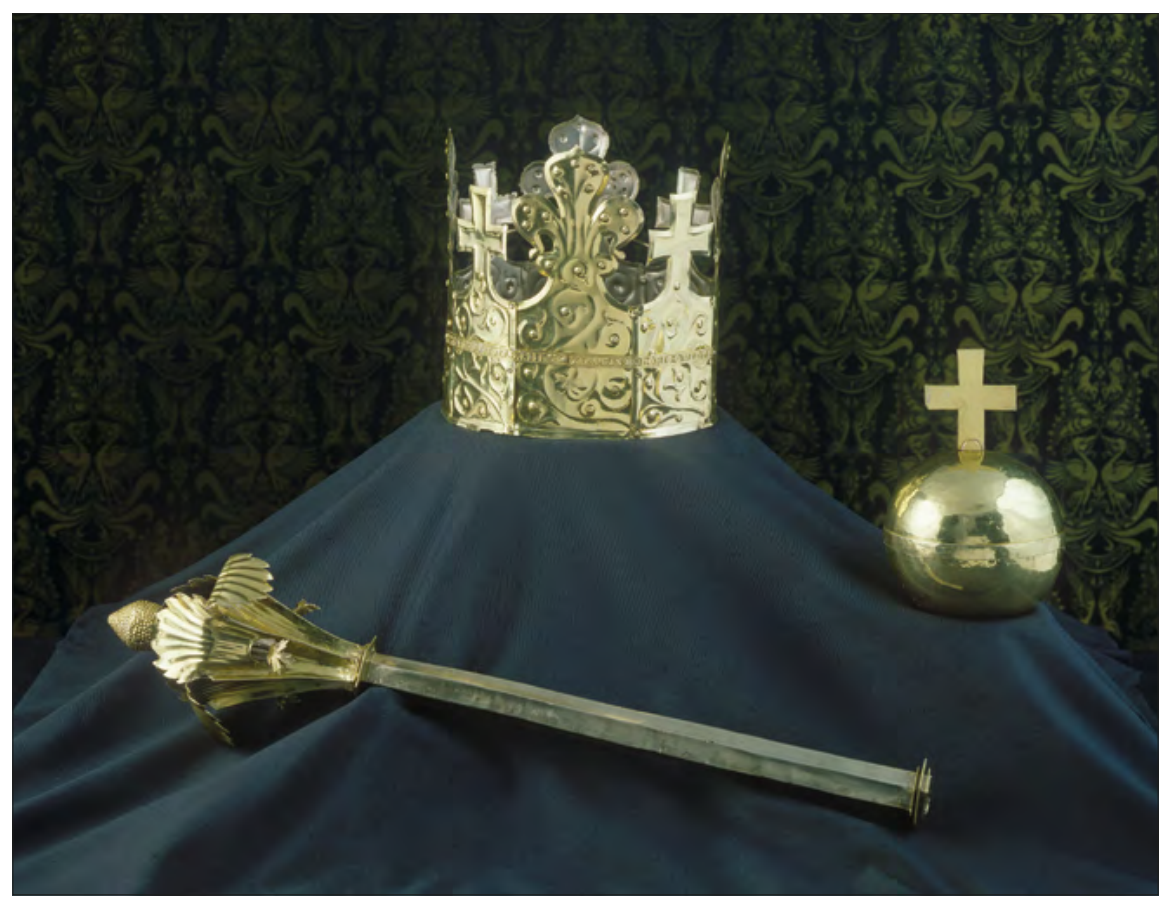

Fig. 7. Funeral jewels from the tomb of Ottokar II (according to Lutovský, Bravermanová 2007).

Chemicals were used to aggressively clean fine fabrics with remnants of gold threads, resulting in the heavy loss of material. A reconstruction of the original form or an interpretation of the entire situation were either not performed or done incorrectly (Bravermanová, Otavská 2000: 4IO). Finally, a hot iron was used to attach a backing with a polymer to the remarkably fine and precious reliquary textiles of St. Ludmila (Bravermanová, Otavská 200I). The Renaissance clothing was also poorly restored: without accompanying documentation, the robes were cleaned with chemicals typically used for removing rust, individual textile fragments were trimmed with scissors and sewn to a new base with darning yarn (Bravermanová et al. 1994: 439-44I).

Although the methods for restoring archaeological metals were perhaps less problematic, mistakes were again made. For example, the funeral jewels of $\mathrm{Ru}$ dolph I Habsburg were galvanically gold-plated in the r960s (Documentation on inv. no. K 268-280). Later, wishing to avoid this procedure during their work with the similar jewels of Ottokar II, restorers did not provide any exterior protection to their surface. The jewels very soon began to corrode again (Documentation on inv. no. PHA 30 ). 


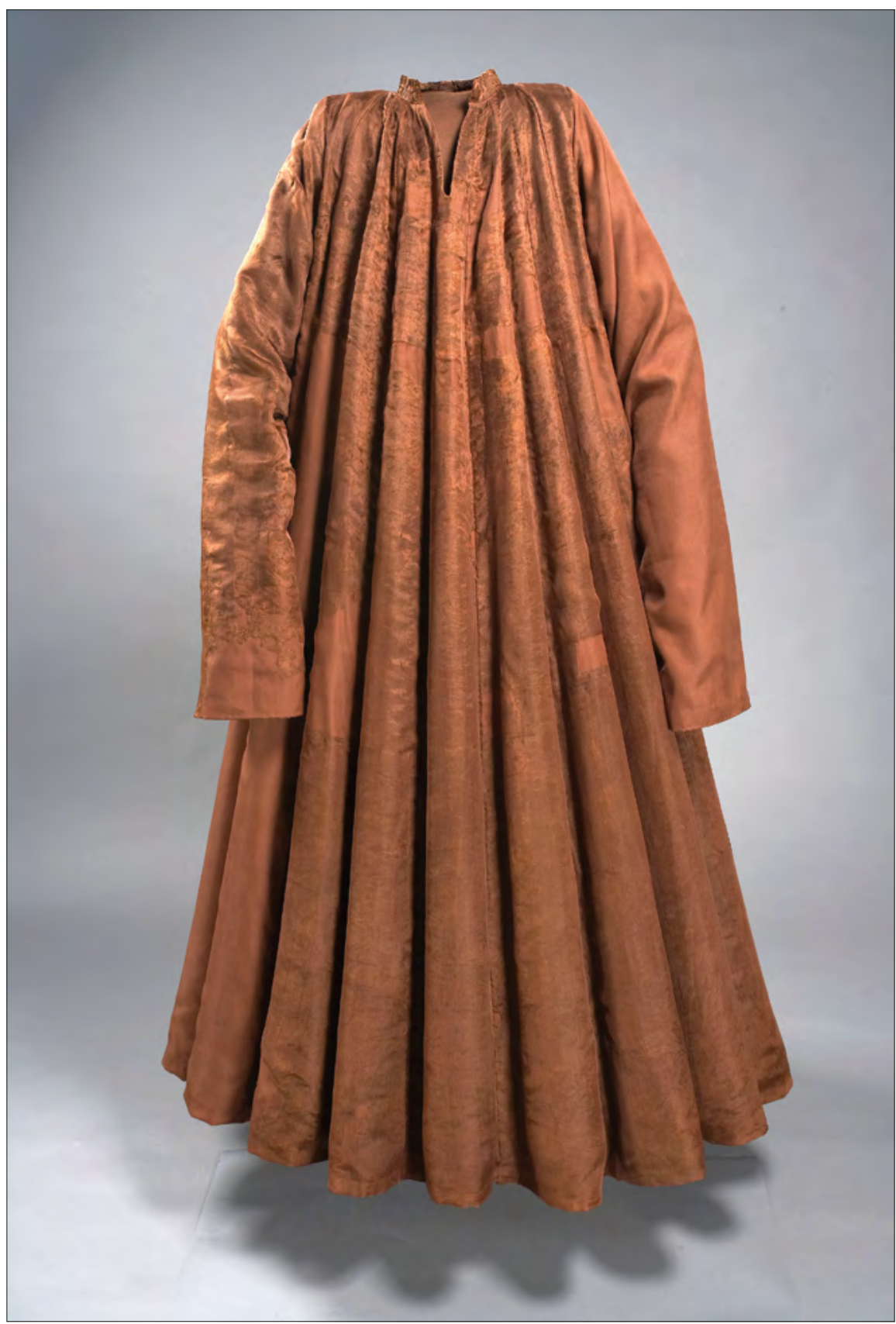

Fig. 8. Dress from the tomb of John of Görlitz (according to Lutovský, Bravermanová 2007). 
The restoration situation improved significantly after the establishment of restoration and conservation workshops in 2000 . Research is now conducted before any measures are taken, and the actual restoration is conservative, with chemicals being use only when it is necessary and justified. The artefacts and methods are documented and conclusions are evaluated and published.

To preserve grave inventories, their deposition in the proper environment with respect to temperature, humidity and light is also extremely important. Protection against harmful insects is also essential. The situation has also improved considerably in this respect in recent years, as new depositories were simultaneously built with the new restoration workshops at Prague Castle. Attention must also be paid to the way the artefacts are displayed, and, recently, architects and heritage administrators have begun to think about how exhibition spaces and the showcases installed in them must meet certain parameters. For example, although the National Museum's historical exhibit opened in 1986 in Lobkowicz Palace at Prague Castle featured impressively massive showcases, because the air was not controlled inside them or in the surrounding room, the funeral jewels of Ottokar II began to corrode soon after the exhibit was opened to the public.

The permanent exhibit "The Story of Prague Castle" opened in 2004 in the Old Royal Palace is already equipped with fully air-conditioned display cases in which both temperature and humidity are controlled.

\section{Conclusion}

The opening of graves is problematic and, from an ethical point of view, should be performed only to a very limited extent. Necessary construction work is a common reason for disruption, and in this case remains should be treated with respect. And if grave goods are removed, they must be cared for in a proper manner, as these artefacts are often irreplaceable heritage whose scientific study is a legitimate pursuit. The mere lust for knowledge, often connected with efforts to generate sensation, does not entitle us to disturb the resting place of our ancestors with ill-considered interventions.

\section{Acknowledgements}

This work was accomplished with support of grant project by Czech Science Foundation GA ČR 19-00166s. 


\section{Bibliography}

\section{Archive resources}

Documentation on inv. no. K 268-280: Dokumentace k inv. č. к 268-280 (unpublished report stored in the Art Collections Department of the Prague Castle Administration).

Documentation on inv. no. PHA 24-26: Dokumentace k inv. č. PHA 24-26 (unpublished report stored in the Art Collections Department of the Prague Castle Administration).

Documentation on inv. no. PHA 30: Dokumentace k inv. č. PHA 30 (unpublished report stored in the Art Collections Department of the Prague Castle Administration).

Documentation on the royal tomb: Dokumentace ke královské hrobce (unpublished report stored in the Art Collections Department of the Prague Castle Administration).

\section{Literature}

Beneš Krabice z Weitmile (I884), [in:] J. Emler (ed.), Fontes rerum bohemicarum, vol. IV, Prague, p. 457-548.

Borkovský I. (1953), Kostel Panny Marie na Pražském hradě - Kostěl Bogorodicy v Pražskom gradè - ÉglisedelaSteViergeau ChâteaudePrague, "Památkyarcheologické",44, p. I29-198.

Borkovský I. (1975), Svatojiřská bazilika a kláster na Pražském hradè, Academia, Prague.

Bravermanová M. (2004), Hroby pražských biskupů v katedrále sv. Vita na Pražském hradě. Předběžné sděleni. Gräber der Prager Bischöfe in der St. Veit Kathedrale auf der Prager Burg, "Archaeologia historica", 29, p. 599-615.

Bravermanová M. (2005), Hroby knižat, Hroby králü, Hroby českých patronů, Hroby významných církevnich činiteli̊. Die Gräben der Fürsten, Die Gräben der Königen, Die Gräben von heiligen Böhmischen Ursprungs, Die Gräben bedeutender vertreter des Geistlichen Standes, [in:] K. Tomková (ed.), Pohřbiváni na Pražském hradě a jeho prèedpolích, vol. I.I, Archeologický ústav Av Čr, Prague (Castrum Pragense, 7), p. 47-I4O.

Bravermanová M. (2006), Hroby světců českého pưvodu na Pražském hradè, [in:] P. Kubín (ed.), Svètci a jejich kult ve středověku, Prague, p. 169-189.

Bravermanová M. (20I6), Pražský hrad jako pohřebišté lucemburské dynastie. Prague Castle as the Burial Site of the Luxembourg Dynasty, [in:] M. Bravermanová, P. Chotěbor (ed.), Koruna království. The Crown of the Kingdom. Katedrála sv. Vita a Karel IV. Charles IV and the Cathedral of St. Vitus, Prague.

BravermanováM., OtavskáV. (2000), Románskátkaninaz královskéhrobkyna Pražském hradě. Ein romanisches Gewebe aus der königlichen Gruft, "Archaeologia historica", 25, p. 405-428.

Bravermanová M., Otavská V. (200I), Nové poznatky o nejstaršich textiliich z hrobu sv. Ludmily. Neue Erkenntisse von den ältesten Textilien aus dem Relikviengrab der Heiligen Ludmila, "Archaeologia historica", 26, p. 447-486.

Bravermanová M., Otavská V. (2013), Křestni obleček novorozence z tumby knižete Břetislava II. v katedrále sv. Vita, [in:] J. Roháček (ed.), Epigraphica and Sepulcralia, vol. Iv, Artefactum, Prague, p. 23-55. 
Bravermanová M., Březinová H., Urbanová K. (2OII), Metodika výzkumu archeologických textilnich nálezü. Forschungsmethodik für archäologische Textilfunde. Methodology of Research of Archaeological Textile Finds, "Zprávy památkové péče”, 7I (I), p. 97-I05, I49, I5I.

Bravermanová M., Kobrlová J., Samohýlová A. (1994), Textilie z hrobu Anny Jagellonské $z$ Colinova mauzolea v katedrále sv. Vita na Pražském hradě. Textilie aus der Grabstätte der Anna Jagellone, "Archaeologia historica", I9, p. 437-46I.

Bravermanová M., Kloudová R., Otavská V., Vrabcová A. (2005), Pohrebni roucho Karla IV. $z$ královské krypty v katedrále sv. Vita. Das Beerdigungsgewand des Karl IV aus der königlichen Krypta in der Kathedrale des Hl. Veit, "Archaeologia historica", 30, p. 47I-496.

Bravermanová M., Dobisíková M., Frolík J., Kaupová S., Stránská P., Světlík I., Vaněk D., Velemínský P., Votrubová J. (2OI8), Nové poznatky o ostatcích z hrobů KI a K2 z rotundy sv. Vita na Pražském hradě. New Findings on the Remains from Graves KI and K2 from the St. Vitus Rotunda at Prague Castle, "Archeologické rozhledy", 70, p. 260-293.

Brůžek J., Novotný V. (1999), Jak staři umirali staři Přemyslovci aneb Jak presná je presnost určeni věku jedince podle kostry, "Vesmír", 8, p. 453-456.

Frolík J. (2005), Hroby Přemyslovských knižat na Pražském hradě. Die Gräber der Přemyslidenfürsten auf der Prager Burg, [in:] K. Tomková (ed.), Pohřbiváni na Pražském hradě a jeho predpolích, vol. I.I, Archeologický ústav AV Čr, Prague (Castrum Pragense, 7), p. 25-46.

Frolík J., Kaupová S. (20I6), Pohřebiště Pražského hradu a možnosti jejich sociální interpretace. Die Gräberfelder der Prager Burg und Möglichkeiten ihrer sozialen Interpretation, "Archaeologia historica", 4I (I), p. IOI-I22, https://doi.org/IO.58I7/AH2OI6-I-6

Frolík J., Boháčová I., Žeglitz J. (1988), Archeologické nálezy z hrobky Spytihněva II. v chrámu sv. Vita. Archaeological Finds from the Tomb of Duke Spytihnèv II in St. Guy Cathedral, [in:] Castrum Pragense, Archeologický ústav Čsav, Prague (Castrum Pragense, I), p. 6I-70.

Gollerová-Plachá J. (1937), Látky z pražské královské hrobky, Státní grafická škola, Prague.

Hilbert K., Matiegka J., Podlaha A. (1928-1930), Královská hrobka v chrámě sv. Vita na Hradě pražském, "Památky archeologické", 36, p. 24I-257.

Kaupová S., Velemínský P., Stránská P., Bravermanová M., Frolíková D., Tomková K., Frolík J. (2018), Dukes, Elites, and Commoners: Dietary Reconstruction of the Early Medieval Population of Bohemia ( $\left(^{\text {th }}-I I^{\text {th }}\right.$ Century AD, Czech Republic), "Archaeological and Anthropological Sciences", II (38), p. I887-I909, https://doi.org/I0.I007/sI2520-0I8-0640-8

Lutovský M., Bravermanová M. (2007), Hroby a hrobky našich knižat, králì a prezidenti̊, Libri, Prague.

Matiegka J. (1932), Tẽlesné pozuistatky českých králì a jejich rodin v hrobce svatovitského chrámu v Praze, Nákladem české akad. věd a umění, Prague, p. IO-I4.

Podlaha A. (I9II), Sv. Václava hrob a ostatky, Nákladem Katolického spolku tiskového, Prague.

Saunders N.J., Frolík J., Heyd V. (2019), Zeitgeist Archaeology: Conflict, Identity and Ideology at Prague Castle, I9I8-20I8, "Antiquity" 93 (370), p. I009-I025, https://doi. org/IO.I5I84/aqy.2019.107

Sláma J. (1983), E. Vlček: Nejstarši Přemyslovci ve světle antropologicko- lékařského výzkumu (review), "Archeologické rozhledy", 35, p. 464-466.

Smetánka Z., Chotěbor P., Kostílková M. (1986), Archaelogical Excavations in the Chapel of St. Ludmila - A Preliminary Report, "Archeologica historica", II, p. 283-293.

Vlček E. (1995), Osudy českých patronů, Zvon, Prague. 
Vlček E. (1997), Nejstarši Přemyslovci. Fyzické osobnosti českých panovniků I, Vesmír, Prague.

Vlček E. (1999), Češtíkrálové, vol. I, Atlaskosternich pozůstatki českých králiu a premyslovskéa lucemburské dynastie s podrobným komentárem a historickými poznámkami, Vesmír, Prague.

Vlček E. (2000), Čeští králové, vol. II, Atlas kosternich pozůstatkù českých králü Ladislava Pohrobka, Jiř́ho z Poděbrad a Habsburků pohřbených na Pražském hradě, Vesmír, Prague.

Votrubova J., Saskova L., Frolik J., Vanek D. (2017), DNA Identification of a $10^{\text {th }}$ Century Female Skeleton from the Prague Castle Belonging to a Member of the Przemyslids Dynasty, "Forensic Science International: Genetics Supplement Series", 6, p. 135-136, https://doi.org/IO.IOI6/j.fsigss.2017.09.029

\section{Summary}

\section{The Fate of the Remains and Funerary Equipment of Czech Rulers and Their Family Members}

Prague Castle was the most important burial site of the Czech rulers and their relatives. The graves are located in the Church of the Virgin Mary, in St. George Church and Convent, and, in the greatest numbers in the St. Vitus Cathedral.

Reliquary tombs of the most important Czech patron saints are also located at Prague Castle - in St. George Basilica, in St. Vitus Cathedral and in All Saints Church. We also know the graves of 12 Prague bishops that are located in the St. Vitus Cathedral.

The majority of the aforementioned graves have been opened several times in the past for a variety of reasons, that caused various problems, the most serious of which involved the confusion of relics.

The first systematic anthropological investigations were conducted at the beginning of the $20^{\text {th }}$ century. The remains of nearly all historical personalities buried at Prague Castle were available for another anthropological study conducted in the 1960s. Currently, the research continues with modern nature science analyzes.

In the past, removed grave goods did not receive proper care for the most part, mainly due to a lack of understanding as to what constituted correct procedures for handling artefacts deposited for years in the unsuitable conditions of graves and tombs. The grave goods themselves were often restored in an inappropriate manner. The restoration situation improved significantly after the establishment of restoration and conservation workshops in 2000.

The opening of graves is problematic and, from an ethical point of view, should be performed only to a very limited extent. Necessary construction work is a common reason for disruption, and in this case remains should be treated with respect. And if grave goods are removed, they must be cared for in a proper manner, as these artefacts are often irreplaceable heritage whose scientific study is a legitimate pursuit. The mere lust for knowledge, often connected with efforts to generate sensation, does not entitle us to disturb the resting place of our ancestors with ill-considered interventions.

Keywords: Prague Castle, Czech rulers, funerary equipment, archaeological textiles, Czech patron saints, Prague bishops, anthropological study 


\section{Streszczenie}

\section{Losy szczątków zmarłych i relikty wyposażenia grobowego czeskich władców i członków ich rodzin}

Zamek Praski był najważniejszym miejscem pochówku czeskich władców i ich krewnych. Groby znajdują się w kościele Matki Boskiej, w kościele i klasztorze pod wezwaniem św. Jerzego oraz, najliczniej, w katedrze św. Wita.

Grobowce z relikwiami najważniejszych świętych patronów Czech również znajdują się na Zamku Praskim w bazylice św.Jerzego, katedrze św. Wita oraz kościele Wszystkich Świętych. Wiemy także o grobach dwunastu praskich biskupów w katedrze św. Wita.

Większość wspomnianych grobów otwierano już kilkukrotnie w przeszłości z różnych powodów, co przysporzyło różnego rodzaju problemów, spośród których najpoważniejszym było mylenie relikwii.

Pierwsze systematyczne badania antropologiczne przeprowadzono na początku xx w. Szczątki niemal wszystkich postaci historycznych pochowanych na Zamku Praskim zostały udostępnione do innego badania antropologicznego przeprowadzonego w latach $60 . \mathrm{xx}$ w. Obecnie trwają dalsze badania obejmujące nowoczesne analizy w zakresie nauk przyrodniczych.

Wydobyte w przeszłości wyposażenie grobowe w większości przypadków nie było należycie traktowane głównie ze względu na brak świadomości prawidłowych procedur postępowania $\mathrm{z}$ artefaktami, które wiele lat spędziły w nieodpowiednich warunkach panujących w grobach i grobowcach. Wyposażenie grobowe często było konserwowane w nieprawidłowy sposób. Poziom konserwacji znacznie wzrósł po tym, jak w $2000 \mathrm{r}$. powstały warsztaty renowacyjno-konserwatorskie.

Otwieranie grobów jest problematyczne, a biorąc pod uwagę kwestie etyczne, powinno do niego dochodzić wyłącznie w ograniczonym zakresie. Częstym powodem są konieczne prace budowlane i w takich przypadkach należy okazywać szczątkom należyty szacunek. Z kolei z wydobywanym wyposażeniem grobowym należy postępować we właściwy sposób, gdyż artefakty te często stanowią niezastąpione dziedzictwo, które należy poddawać naukowym analizom. Sam głód wiedzy, często związany z próbą wywołania sensacji, nie upoważnia nas do zakłócania miejsc pochówku naszych przodków nieprzemyślanymi działaniami.

Słowa kluczowe: Zamek Praski, władcy Czech, wyposażenie grobowe, tekstylia archeologiczne, czescy święci patroni, biskupi prascy, badania antropologiczne

Milena Bravermanová

Institute of Archaeology of the CAS

Prague, Czech Republic

e-mail: milena.bravermanova@seznam.cz

Helena Březinová

Institute of Archaeology of the CAS

Prague, Czech Republic

e-mail: brezinova@arup.cas.cz 